\title{
Analysis of C1s Spectra of N-, O-, and $X$-Containing Polymers in X-Ray Photoelectron Spectroscopy by $A b$ Initio Molecular Orbital Calculations Using Model Molecules
}

\author{
Kazunaka Endo, Shigehiro MaEdA, and Yasuo KanedA \\ Tsukuba Research Laboratory, Mitsubishi Paper Mills, Ltd., \\ 46 Wadai, Tsukuba-shi, Ibaraki 300-42, Japan
}

(Received September 5, 1996)

\begin{abstract}
Cls}$ X-ray photoelectron spectra of ten polymers $\left[\left(\mathrm{CH}_{2}-\mathrm{CH}_{2}-\mathrm{NH}\right)_{n},\left(\mathrm{CH}_{2}-\mathrm{CHR}\right)_{n}\left(\mathrm{R}=\mathrm{CN}, \mathrm{CONH}{ }_{2}, \mathrm{~F}\right.\right.$, $\left.\mathrm{OCOCF}_{3}, \mathrm{COOCH}_{2} \mathrm{CF}_{3}, \mathrm{Cl}\right),\left(\mathrm{CH}_{2}\left(\mathrm{CH}_{2}\right)_{3} \mathrm{CH}_{2}-\mathrm{CONH}\right)_{n},\left(\mathrm{CH}_{2}-\mathrm{CX}_{2}\right)_{n}(\mathrm{X}=\mathrm{F}, \mathrm{Cl})$ ] were simulated from Koopmans' theorem by an ab initio molecular orbital (MO) calculations of HONDO7 program using the model molecules. The theoretical spectra showed fairly good accordance with the experimental spectra, although we used the energy shifted value and the linewidth of a Gaussian lineshape function for each core $\mathrm{Cls}$ MO value as $21.0 \mathrm{eV}$ and $1.3 \mathrm{eV}$, respectively. The core-electron binding energies (CEBEs) of $\mathrm{Cls}$ for model molecules of polymers $\left[\left(\mathrm{CH}_{2}-\mathrm{CH}_{2}-\mathrm{NH}\right)_{n},\left(\mathrm{CH}_{2}-\mathrm{CHR}\right)_{n}(\mathrm{R}=\mathrm{CN}, \mathrm{F}, \mathrm{Cl}),\left(\mathrm{CH}{ }_{2}-\mathrm{CX}\right)_{n}\right.$ $(\mathrm{X}=\mathrm{F}, \mathrm{Cl})$ ] were calculated by deMon density functional theory program with scaled polarized valence triple-zeta (scaled-pVTZ) basis set. The WD (sum of work funktion and other energy effects) of the polymers was evaluated as $5.2-6.4 \mathrm{eV}$ from the difference between the calculated CEBEs of the model molecules and the experimental CEBEs of the polymers.

KEY WORDS X-Ray Photoelectron Spectroscopy / Cls spectra / Ab Initio Molecular Orbital / Spectral

Simulation / Koopmans' Theorm / N- and X-Containing Polymer / Work Function /
\end{abstract}

In the previous works, ${ }^{1-4}$ we simulated $C_{1 \mathrm{~s}}$ spectra of polymers in X-ray photoelectron spectroscopy (XPS) with Koopmans' values by ab initio molecular orbital (MO) calculations using the model oligomers. The reason relies on it that the differences between core energy levels as obtained using calculations of the neutral parent molecules approach the ones as observed for the ionized molecule in XPS, although the nuclear positive charges strongly attract core electrons in the deep potential of ionized state. Here, an aim is to simulate the C1s spectra of N-, O-, F-, and Cl-containing polymers by Koopmans' theorem. We describe the comprehensive study on the analysis of C1s spectra of ten polymers in XPS by an $a b$ initio $\mathrm{MO}$ calculations of $\mathrm{HONDO} 7$ program $^{5}$ using the model molecules $\left[\mathrm{H}-\left(\mathrm{CH}_{2}-\mathrm{CH}_{2}-\mathrm{NH}\right)_{2}-\mathrm{H}, \mathrm{H}-\left(\mathrm{CH}_{2}-\right.\right.$ $\mathrm{CHR})_{k}-\mathrm{H} \quad\left(\mathrm{R} ; k=\mathrm{CN} ; 2, \mathrm{CONH}_{2} ; 2, \quad \mathrm{~F} ; 3, \mathrm{Cl} ; 3\right)$, $\mathrm{H}_{3} \mathrm{C}-\left(\mathrm{CH}_{2}-\mathrm{CHR}\right)-\mathrm{CH}_{3}\left(R=\mathrm{OCOCF}_{3}, \mathrm{COOCH}_{2} \mathrm{CF}_{3}\right)$, $\mathrm{H}_{2} \mathrm{~N}-\left(\mathrm{CH}_{2}\left(\mathrm{CH}_{2}\right)_{3} \mathrm{CH}_{2}-\mathrm{CONH}\right)-\mathrm{CH}_{3}, \mathrm{H}-\left(\mathrm{CH}_{2}-\right.$ $\left.\left.\mathrm{CX}_{2}\right)_{k}-\mathrm{H}(\mathrm{X} ; k=\mathrm{F} ; 3, \mathrm{Cl} ; 2)\right]$. Furthermore, the coreelectron binding energies (CEBEs) of $\mathrm{C} 1 \mathrm{~s}$ for the model molecules $\left[\mathrm{H}-\left(\mathrm{CH}_{2}-\mathrm{CH}_{2}-\mathrm{NH}\right)_{2}-\mathrm{H}, \mathrm{H}-\left(\mathrm{CH}_{2}-\mathrm{CHCN}\right)-\right.$ $\mathrm{CH}_{3}, \mathrm{H}-\left(\mathrm{CH}_{2}-\mathrm{CHX}\right)_{2}-\mathrm{H}(\mathrm{X}=\mathrm{F}, \mathrm{Cl}), \mathrm{H}-\left(\mathrm{CH}_{2}-\mathrm{CX}_{2}\right)_{2}-$ $\mathrm{H}(\mathrm{X}=\mathrm{F}, \mathrm{Cl})]$ of six polymers were calculated by deMon density-functional calculations ${ }^{6}$ with scaled polarized valence triple-zeta (pVTZ) basis set. The WD values of the six polymers were estimated from the difference between the calculated CEBEs and the experimental CEBEs of the polymers.

\section{THEORETICAL AND DETAIL OF CALCULATION}

Spectral Simulation of Cls Due to Koopmans' Theorem The model molecules $\left[\mathrm{H}-\left(\mathrm{CH}_{2}-\mathrm{CH}_{2}-\mathrm{NH}\right)_{2}-\mathrm{H}, \mathrm{H}-\right.$ $\left(\mathrm{CH}_{2}-\mathrm{CHR}\right)_{k}-\mathrm{H}\left(\mathrm{R} ; k=\mathrm{CN} ; 2, \mathrm{CONH}_{2} ; 2, \mathrm{~F} ; 3, \mathrm{Cl} ; 3\right)$, $\mathrm{H}_{3} \mathrm{C}-\left(\mathrm{CH}_{2}-\mathrm{CHR}\right)-\mathrm{CH}_{3}\left(\mathrm{R}=\mathrm{OCOCF}_{3}, \mathrm{COOCH}_{2} \mathrm{CF}_{3}\right)$, $\mathrm{H}_{2} \mathrm{~N}-\left(\mathrm{CH}_{2}\left(\mathrm{CH}_{2}\right)_{3} \mathrm{CH}_{2}-\mathrm{CONH}\right)-\mathrm{CH}_{3}, \mathrm{H}-\left(\mathrm{CH}_{2}-\right.$ $\left.\left.\mathrm{CX}_{2}\right)_{2}-\mathrm{H}(\mathrm{X}=\mathrm{F}, \mathrm{Cl})\right]$ were calculated by the $a b$ initio
RHF-SCF MO calculations using the HONDO7 program. For $(\mathrm{C}, \mathrm{N}, \mathrm{O}, \mathrm{F})$ and $\mathrm{Cl}$ atoms, we used the (3s $2 \mathrm{p})$ and $(4 s 4 p)$ basis sets, respectively, and for $\mathrm{H}$ atoms, we used $2 \mathrm{~s}$ basis set reported by Huzinaga et al. ${ }^{7}$ and Dunning et $a l^{8}{ }^{8}$ For the geometry of the molecules, we used the optimized cartesian coordinates from the semiempirical AM1 (version 6.0) method. ${ }^{9}$

The electronic states of the polymers by the MO calculations using the monomer, dimer or trimer model molecules will enhance the effects of the edges of the main chain. Then, we omitted the contribution of both edge segments of the main chain, in order to simulate the $\mathrm{C} 1$ s core-electron spectra.

For the comparison between calculations for single molecules of the monomer, dimer or trimer models and experiments on a solid polymer, we shifted each computed CEBEs, $E_{\mathrm{k}}^{\prime}$ by a quantity $\left(E_{\mathrm{DKT}}+W D\right)$ as $E_{\mathrm{k}}\left(E_{\mathrm{F}}\right)=$ $E_{\mathrm{k}}^{\prime}-\left(E_{\mathrm{DKT}}+W D\right)$, to convert to core-electron binding energy $E_{\mathrm{k}}\left(E_{\mathrm{F}}\right)$ relative to the Fermi level. In this work, we chose the fixed approximate value of the sum $\left(E_{\mathrm{DKT}}+W D\right)$ as $21.0 \mathrm{eV}$ for C1s CEBEs of model molecules, as stated in the previous work. ${ }^{4}$

In order to simulate the core-electron spectra of $\mathrm{C} 1 \mathrm{~s}$ of polymers, we used the Gaussian lineshape function, as was done in previous works. ${ }^{3,4}$ For the linewidth $(W H(k))$, we used the fixed approximated value as $1.3 \mathrm{eV}$ for each $\mathrm{C} 1 \mathrm{~s}$ CEBE of polymer models.

\section{CEBEs of C1s Due to the Slater's Transition State Using DFT Calculations}

As stated in the previous work, ${ }^{4}$ in the generalized transition-states (GTS) method, Williams et al. ${ }^{10}$ proposed the extension of Slater's transition-state idea ${ }^{11}$ and approximated the endothermicity $\Delta E=E(1)-E(0)$ by

$$
\Delta E=[F(0)+3 F(2 / 3)] / 4,
$$

where $F(x)=\mathrm{d} E(x) / \mathrm{d} x$ and $x$ is assumed to be a con- 
tinuous variable, with $E(0)$ and $E(1)$ denoting the energies of the initial and final states, respectively. For ionization of an electron from molecular orbital (MO) $\phi_{\mathrm{k}}$, for example, we can apply the Janak theorem ${ }^{12}$ and set $F(x)$ to $-\varepsilon_{\mathrm{k}}(x)$. The procedure is applied in the following way. In the unrestricted GTS model in this work, we remove $2 / 3$ alpha electron from MO $\phi_{\mathrm{k}}$ of interest.

The model molecules of six polymers $\left[\left(\mathrm{CH}_{2}-\mathrm{CH}_{2}-\right.\right.$ $\mathrm{NH})_{n}, \quad\left(\mathrm{CH}_{2}-\mathrm{CHR}\right)_{n}(\mathrm{R}=\mathrm{CN}, \mathrm{F}, \mathrm{Cl}),\left(\mathrm{CH}_{2}-\mathrm{CX}_{2}\right)_{n}$ $(\mathrm{X}=\mathrm{F}, \mathrm{Cl})$ ] were calculated by the density functional method using deMon program. For the geometry of the molecules, we used the optimized cartesian coordinates from the semiempirical AM1 (version 6.0) method. ${ }^{9}$ The deMon calculations were performed with the exchangecorrelation potential labeled as B88/P86, made from Beck's 1988 exchange functional ${ }^{13}$ and Perdew's 1986 correlation functional. ${ }^{14}$ In the program, we used a nonrandom grid and a scaled polarized valence triple-zeta (scaled-pVTZ) ${ }^{15}$ basis set for C, N, O, F, Cl, and $\mathrm{H}$ with auxiliary fitting functions labeled $(4,4 ; 4,4)$ for $\mathrm{C}, \mathrm{N}$, $\mathrm{O}$, and $\mathrm{F}(3,1 ; 3,1)$ for $\mathrm{H}$ and $(5,4 ; 5,4)$ for $\mathrm{Cl}$.

In the calculation of CEBEs, we used the uGTS models for the model molecules of six polymers. Following the previous paper, ${ }^{4}$ we added relativistic correlation correction $(\mathrm{Crel})$ for the second-period atoms.

For ten polymers, we cited the experimental $\mathrm{C} 1 \mathrm{~s}$ spectra in XPS by Beamson and Briggs. ${ }^{16}$

\section{RESULTS AND DISCUSSION}

\section{Simulation of C1s Spectra of Ten Polymers}

In the case of the spectral analysis, we omitted the contribution of both edge segments of main chain. The

Table I. Cls binding energies (in eV) of N-, O-, and X-containing polymers by HONDO7 program using the model molecules ${ }^{\mathrm{a}}$

\begin{tabular}{|c|c|c|c|c|c|}
\hline Polymer & Observed $^{\mathrm{b}}$ & $\begin{array}{c}\text { Koopmans' } \\
\text { theorem }\end{array}$ & $\begin{array}{l}\text { Relative } \\
\text { intensity }\end{array}$ & $\begin{array}{c}\text { Shifted } \\
\text { value }\end{array}$ & $\begin{array}{l}\text { Linewidth } \\
\text { (halfwidth) }\end{array}$ \\
\hline $\begin{array}{l}\left(\mathrm{CH}_{2}-\mathrm{CH}_{2}-\mathrm{NH}\right)_{n} \\
\quad \mathrm{CEBE}(\mathrm{Cls})\left[\mathrm{CH}_{2-}^{-}\right]\end{array}$ & 285.6 & $\begin{array}{c}(2 \text { mer }) \\
305.8 ; 306.0\end{array}$ & 1.0 & 21.0 & 1.3 \\
\hline $\begin{array}{c}\left(\mathrm{CH}_{2}-\mathrm{CH}(\mathrm{CN})\right)_{n} \\
\mathrm{CEBE}(\mathrm{Cls})\left[\mathrm{CH}_{2}-\right] \\
\mathrm{CEBE}(\mathrm{Cls})[-\underline{\mathrm{CH}}] \\
\mathrm{CEBE}(\mathrm{Cls})[-\underline{\mathrm{C}}]\end{array}$ & $\begin{array}{l}285.5 \\
286.4 \\
286.7\end{array}$ & $\begin{array}{l}(2 \mathrm{mer}) \\
305.6 \\
306.8 \\
307.0\end{array}$ & $\begin{array}{l}1.0 \\
1.0 \\
1.0\end{array}$ & $\begin{array}{l}21.0 \\
21.0 \\
21.0\end{array}$ & $\begin{array}{l}1.3 \\
1.3 \\
1.3\end{array}$ \\
\hline $\begin{array}{l}\left.\left(\mathrm{CH}_{2}-\mathrm{CH}(\mathrm{CONH})_{2}\right)\right)_{n} \\
\text { CEBE }(\mathrm{Cls})\left[\mathrm{CH}_{2}-\right] \\
\text { CEBE }(\mathrm{Cls})\left[\underline{\mathrm{C}}-\mathrm{H}_{-}^{-}\right] \\
\left.\quad \mathrm{CEBE}(\mathrm{Cls})\left[\underline{\mathrm{CONH}} \mathrm{ON}_{2}\right)\right]\end{array}$ & $\begin{array}{l}285.0 \\
285.3 \\
288.6\end{array}$ & $\begin{array}{c}(2 \mathrm{mer}) \\
305.2 \\
306.0 \\
309.2\end{array}$ & $\begin{array}{l}1.0 \\
1.0 \\
1.0\end{array}$ & $\begin{array}{l}21.0 \\
21.0 \\
21.0\end{array}$ & $\begin{array}{l}1.3 \\
1.3 \\
1.3\end{array}$ \\
\hline $\begin{array}{c}\left(\mathrm{CH}_{2}\left(\mathrm{CH}_{2}\right)_{3} \mathrm{CH}_{2}-\mathrm{CONH}\right)_{n} \\
\mathrm{CEBE}(\mathrm{Cls})\left[\mathrm{CH}_{2}-\right] \\
\mathrm{CEBE}(\mathrm{Cls})\left[\underline{\mathrm{C}} \mathrm{H}_{2}-\mathrm{CO}\right] \\
\mathrm{CEBE}(\mathrm{Cls})\left[\mathrm{NH}-\mathrm{CH}_{2}\right] \\
\left.\text { CEBE }(\mathrm{Cls})\left[\mathrm{CONH}_{2}\right)\right]\end{array}$ & $\begin{array}{l}285.0 \\
285.3 \\
286.0 \\
288.0\end{array}$ & $\begin{array}{c}(1 \mathrm{mer}) \\
305.1 ; 305.1 ; 305.2 \\
305.8 \\
306.9 \\
309.0\end{array}$ & $\begin{array}{l}1.0 \\
1.0 \\
1.0 \\
1.0\end{array}$ & $\begin{array}{l}21.0 \\
21.0 \\
21.0 \\
21.0\end{array}$ & $\begin{array}{l}1.3 \\
1.3 \\
1.3 \\
1.3\end{array}$ \\
\hline $\begin{array}{l}\left(\mathrm{CH}_{2}-\mathrm{CHF}\right)_{n} \\
\quad \mathrm{CEBE}(\mathrm{Cls})\left[\mathrm{CH}_{2}-\right] \\
\text { CEBE (Cls) }[\underline{\mathrm{C}} \mathrm{HF}]\end{array}$ & $\begin{array}{l}285.7 \\
287.9\end{array}$ & $\begin{array}{c}(3 \mathrm{mer}) \\
306.1 ; 306.2 \\
308.3 ; 308.4\end{array}$ & $\begin{array}{l}1.0 \\
1.0\end{array}$ & $\begin{array}{l}21.0 \\
21.0\end{array}$ & $\begin{array}{l}1.3 \\
1.3\end{array}$ \\
\hline $\begin{array}{l}\left(\mathrm{CH}_{2}-\mathrm{CF}_{2}\right)_{n} \\
\quad \mathrm{CEBE}(\mathrm{Cls})\left[\mathrm{CH}_{2}-\right] \\
\text { CEBE }(\mathrm{Cls})\left[\mathrm{CF}_{2}-\right]\end{array}$ & $\begin{array}{l}286.4 \\
290.9\end{array}$ & $\begin{array}{c}(3 \mathrm{mer}) \\
307.2 ; 307.3 \\
311.3 ; 311.6\end{array}$ & $\begin{array}{l}1.0 \\
1.0\end{array}$ & $\begin{array}{l}21.0 \\
21.0\end{array}$ & $\begin{array}{l}1.3 \\
1.3\end{array}$ \\
\hline $\begin{array}{c}\left(\mathrm{CH}_{2}-\mathrm{CH}\left(\mathrm{OCOCF}_{3}\right)\right)_{n} \\
\mathrm{CEBE}(\mathrm{Cls})\left[\mathrm{CH}_{2}-\right] \\
\mathrm{CEBE}(\mathrm{Cls})[-\mathrm{CH}] \\
\text { CEBE }(\mathrm{Cls})[-\mathrm{C}=\mathrm{O}] \\
\text { CEBE }(\mathrm{Cls})\left[-\underline{\mathrm{C}}_{3}\right]\end{array}$ & $\begin{array}{l}285.0 \\
286.7 \\
289.5 \\
292.7\end{array}$ & $\begin{array}{l}(1 \mathrm{mer}) \\
306.0 \\
308.5 \\
311.6 \\
314.7\end{array}$ & $\begin{array}{l}1.0 \\
1.0 \\
1.0 \\
1.0\end{array}$ & $\begin{array}{l}21.0 \\
21.0 \\
21.0 \\
21.0\end{array}$ & $\begin{array}{l}1.3 \\
1.3 \\
1.3 \\
1.3\end{array}$ \\
\hline $\begin{array}{l}\left(\mathrm{CH}_{2}-\mathrm{CH}\left(\mathrm{COOCH}_{2} \mathrm{CF}_{3}\right)\right)_{n} \\
\mathrm{CEBE}(\mathrm{Cls})\left[\mathrm{CH}_{2}-\right] \\
\mathrm{CEBE}(\mathrm{Cls})[-\underline{\mathrm{CH}}] \\
\text { CEBE }(\mathrm{Cls})\left[-\mathrm{O}-\underline{\mathrm{C}} \mathrm{H}_{2-}\right] \\
\text { CEBE }(\mathrm{Cls})[-\mathrm{C}=\mathrm{O}] \\
\text { CEBE }(\mathrm{Cls})\left[-\underline{\mathrm{C}}_{3}\right]\end{array}$ & $\begin{array}{l}285.0 \\
285.4 \\
287.4 \\
289.1 \\
292.7\end{array}$ & $\begin{array}{l}(1 \mathrm{mer}) \\
305.8 \\
306.6 \\
308.8 \\
310.8 \\
314.0\end{array}$ & $\begin{array}{l}1.0 \\
1.0 \\
1.0 \\
1.0 \\
1.0\end{array}$ & $\begin{array}{l}21.0 \\
21.0 \\
21.0 \\
21.0 \\
21.0\end{array}$ & $\begin{array}{l}1.3 \\
1.3 \\
1.3 \\
1.3 \\
1.3\end{array}$ \\
\hline $\begin{array}{l}\left(\mathrm{CH}_{2}-\mathrm{CHCl}\right)_{n} \\
\mathrm{CEBE}(\mathrm{Cls})\left[\mathrm{CH}_{2}-\right] \\
\text { CEBE }(\mathrm{Cls})[\underline{\mathrm{C}} \mathrm{HCl}]\end{array}$ & $\begin{array}{l}285.9 \\
287.0\end{array}$ & $\begin{array}{c}(3 \mathrm{mer}) \\
306.6 ; 306.7 \\
308.1 ; 308.3\end{array}$ & $\begin{array}{l}1.0 \\
1.0\end{array}$ & $\begin{array}{l}21.0 \\
21.0\end{array}$ & $\begin{array}{l}1.3 \\
1.3\end{array}$ \\
\hline $\begin{array}{l}\left(\mathrm{CH}_{2}-\mathrm{CCl}_{2}\right)_{n} \\
\quad \mathrm{CEBE}(\mathrm{Cls})\left[\mathrm{CH}_{2}-\right] \\
\text { CEBE }(\mathrm{Cls})\left[\mathrm{CCl}_{2}\right]\end{array}$ & $\begin{array}{l}286.2 \\
288.6\end{array}$ & $\begin{array}{l}(2 \mathrm{mer}) \\
307.7 \\
310.4\end{array}$ & $\begin{array}{l}1.0 \\
1.0\end{array}$ & $\begin{array}{l}21.0 \\
21.0\end{array}$ & $\begin{array}{l}1.3 \\
1.3\end{array}$ \\
\hline
\end{tabular}

${ }^{a}$ We omitted the contribution of both edge segments of the main chain. ${ }^{b}$ Values were referred to G. Beamson and D. Briggs, "High Resolution XPS of Organic Polymers. The Scienta ESCA 3000 Database.” Wiley, Chichester, 1992. 
C1s relative intensity of each functional group for the model molecules was considered as the number of the carbon for the functional group in the monomer unit of the ten polymers in Table I. In the table, we used an energy shifted value and a linewidth of each MO levels as 21.0 and $1.3 \mathrm{eV}$, respectively, as stated in the previuos

a)

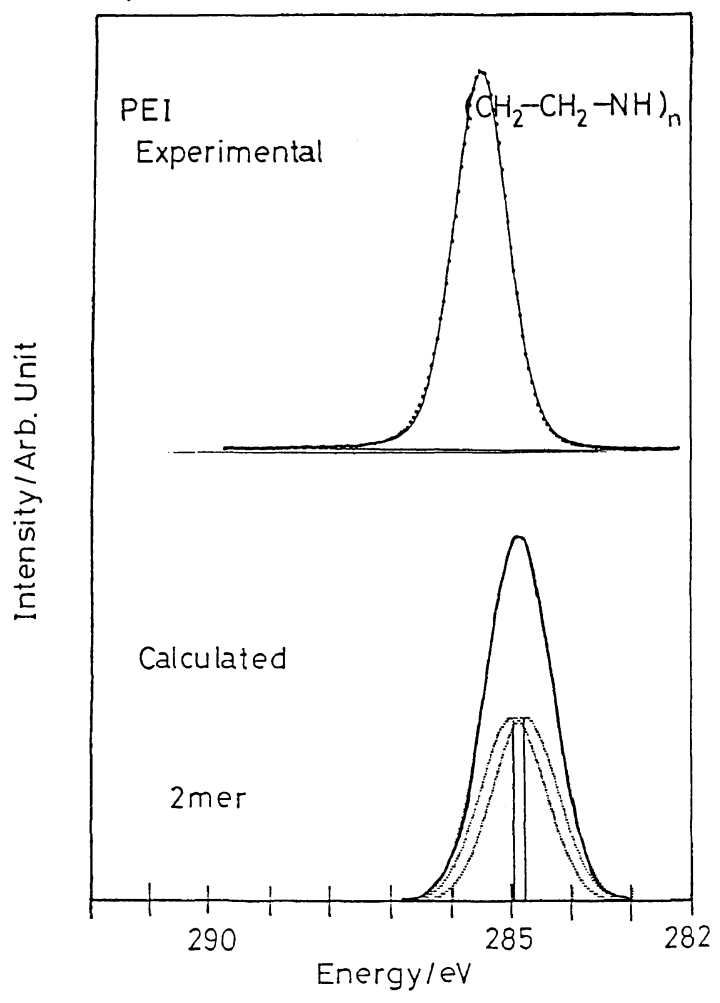

c)

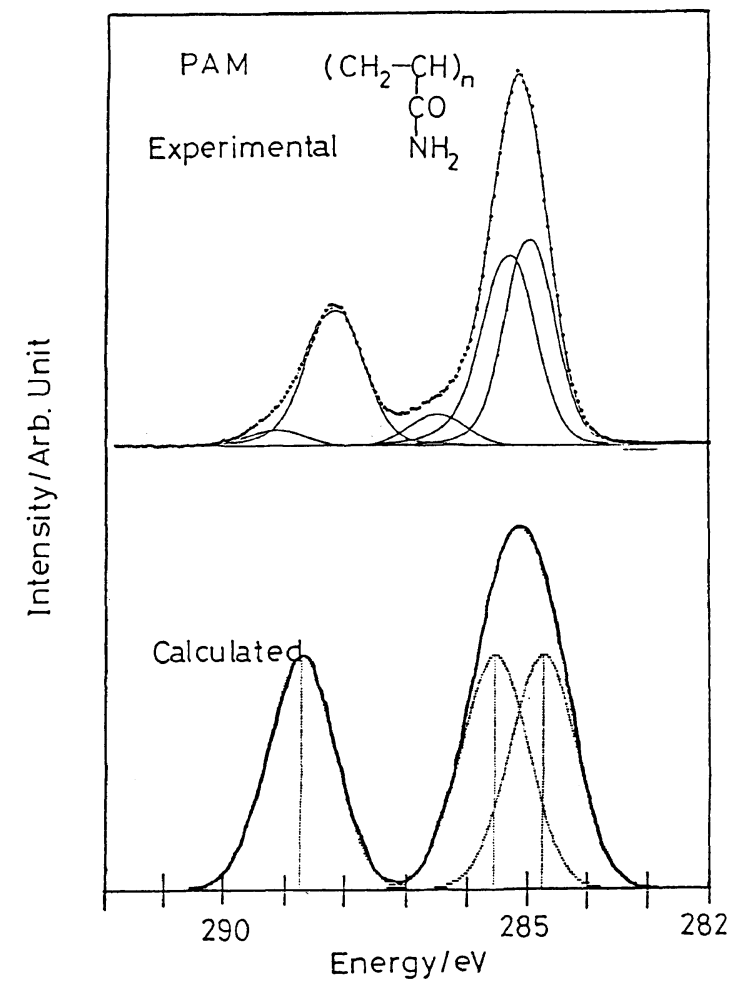

work. ${ }^{4}$

The simulated C1s spectra as obtained by MO calculations using model molecules are in good accordance with the experimental core electron spectra ${ }^{16}$ of the polymers (as shown in Figures 1a) - 3b)), although there was a large difference $(21.0 \mathrm{eV})$ in energy levels due to

b)

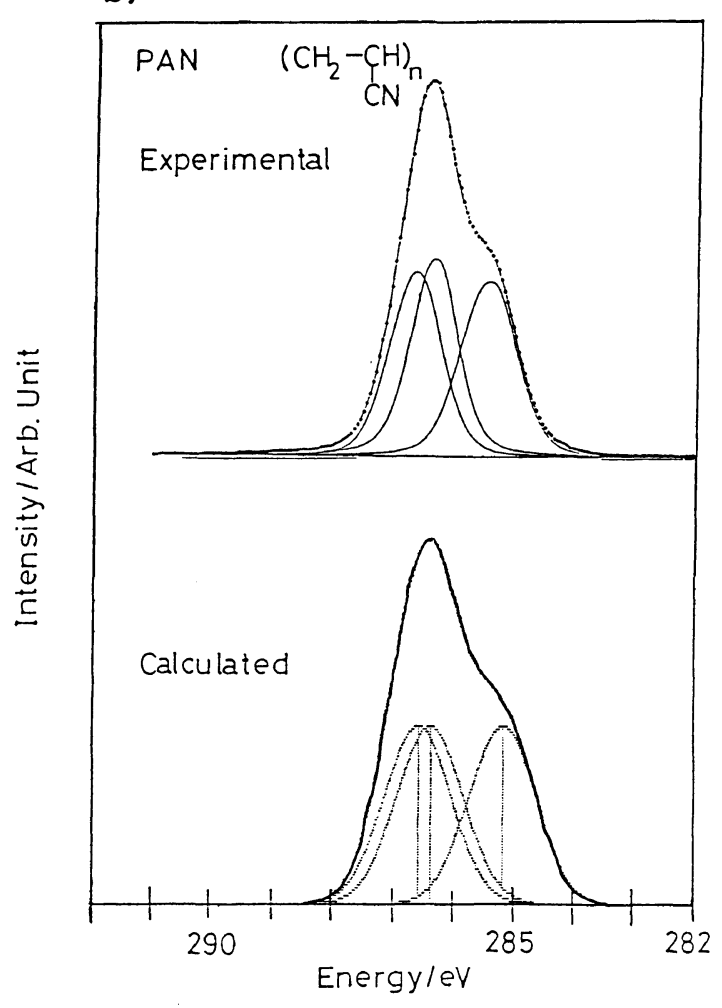

d)

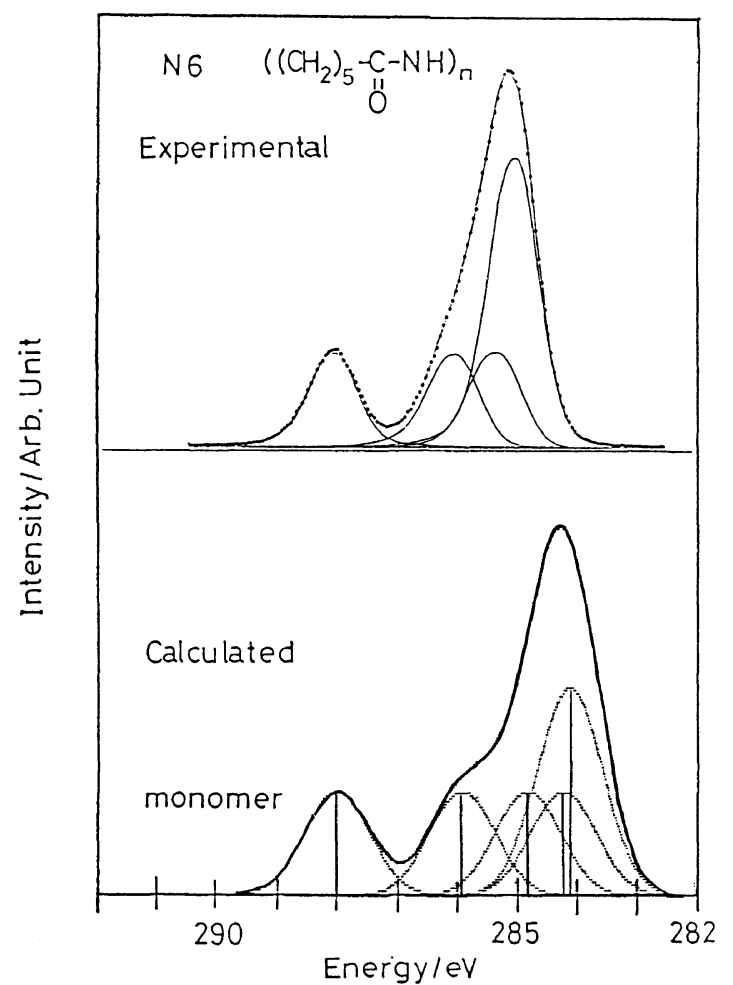

Figure 1. Core C1s X-ray photoelectron spectra of N-containing polymers with the simulated spectra of the model molecules using HONDO7 program. a) PEI; b) PAN; c) PAM; d) N6. 
the Koopmans' value and $W D$ (work function and other energy effects). We emphasize here that theoretical results provide an aid to perform experimental lineshape analysis. In the case of nylon6 (N6) in Figure 1d), the large peak around $285 \mathrm{eV}$ results from the calculated values, 306.9, 305.8 and $(305.1,305.1,305.2)$ of the

\section{a)}

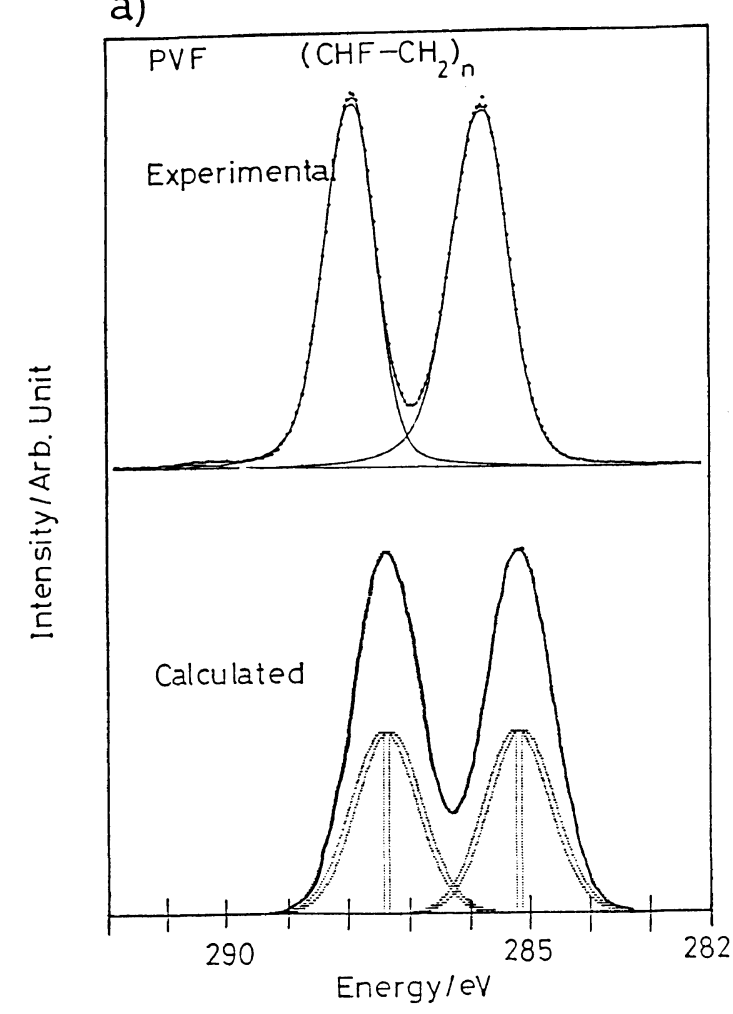

c)

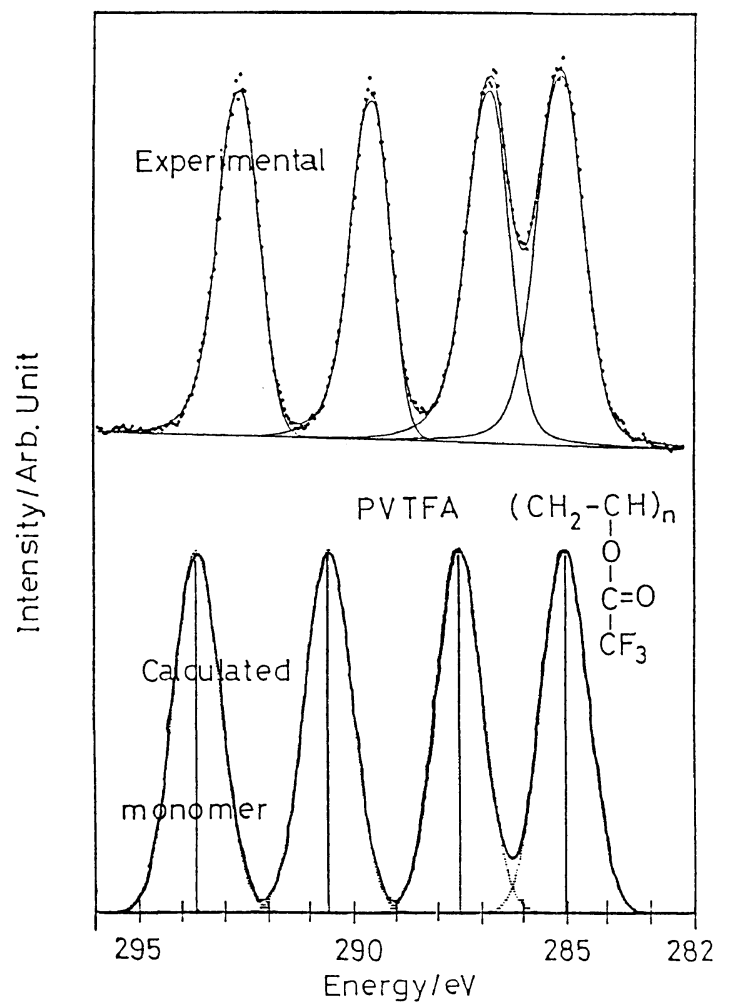

$\left(\mathrm{NH}-\mathrm{CH}_{2}\right),\left(\mathrm{CH}_{2}-\mathrm{CO}\right)$, and $\left(\underline{\mathrm{CH}}_{2}\right)_{3}$ methylene groups, respectively for the model molecule. For the F- and Cl-containing polymers (Figures $2 a)-3 b$ )), each simulated peak is in good accordance with the results from the experimental lineshape analysis.

b)

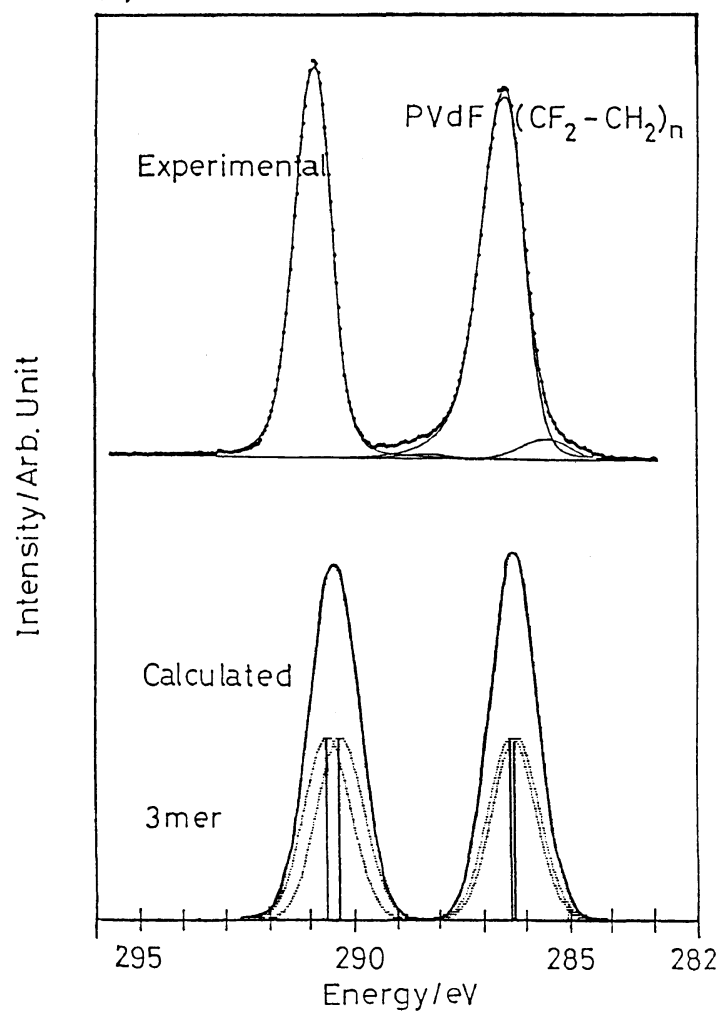

d)

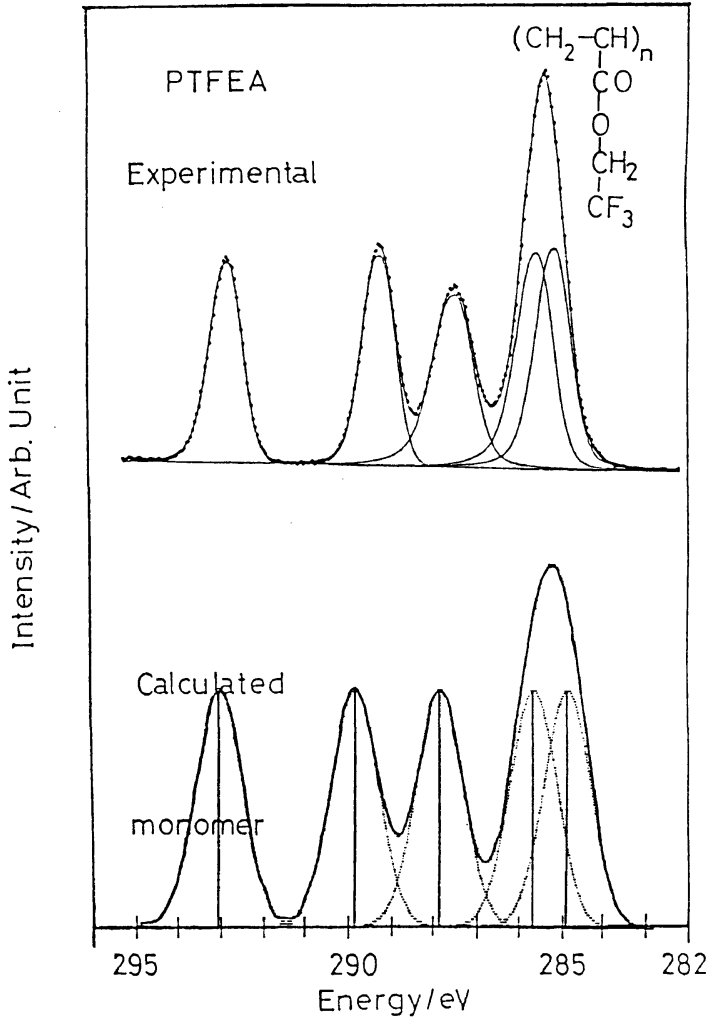

Figure 2. Core $\mathrm{Cls} \mathrm{X}$-ray photoelectron spectra of F-containing polymers with the simulated spectra of the model molecules using HONDO7 program. a) PVF; b) PVDF; c) PVTFA; d) PTFEA. 
a)

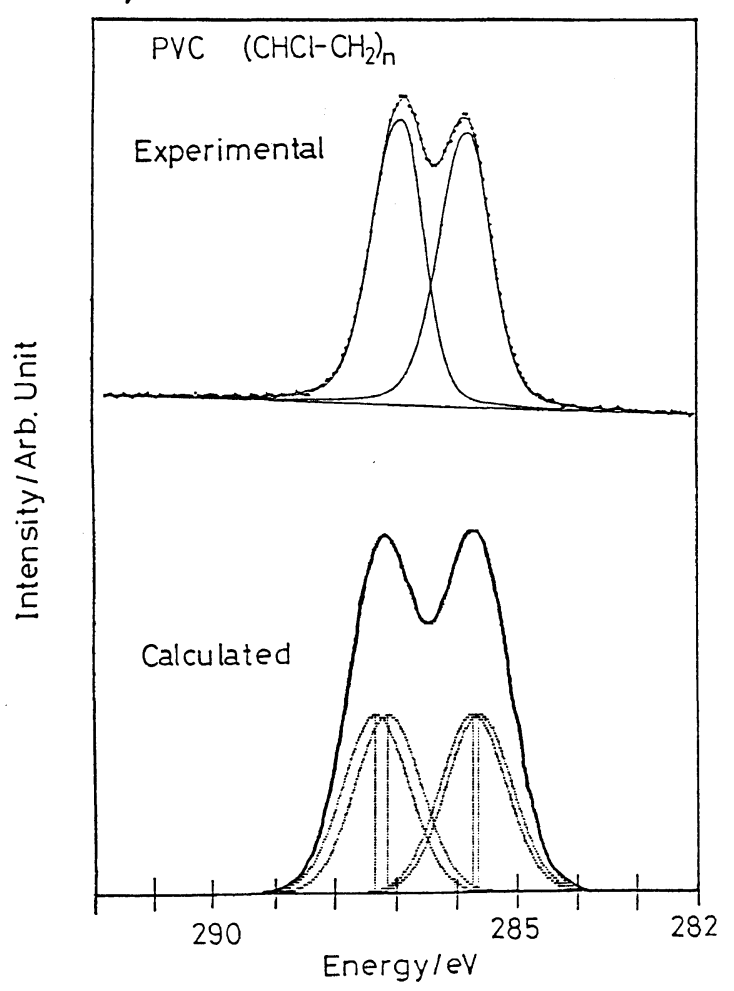

b)

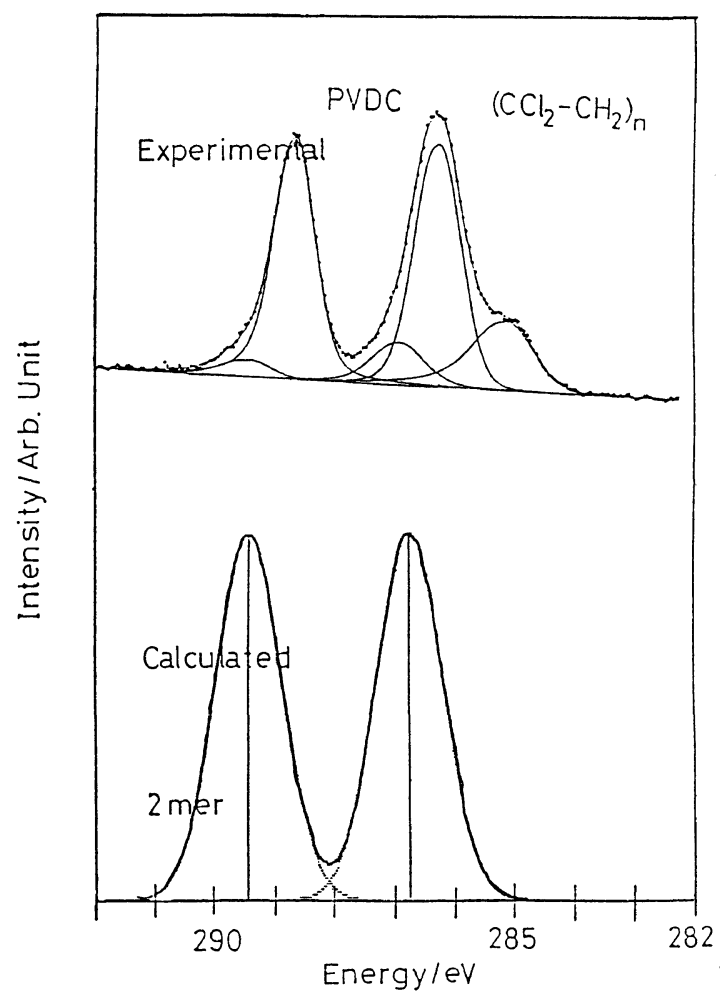

Figure 3. Core $\mathrm{Cls}$ X-ray photoelectron spectra of $\mathrm{Cl}$-containing polymers with the simulated spectra of the model molecules using HONDO7 program. a) PVC; b) PVDC.

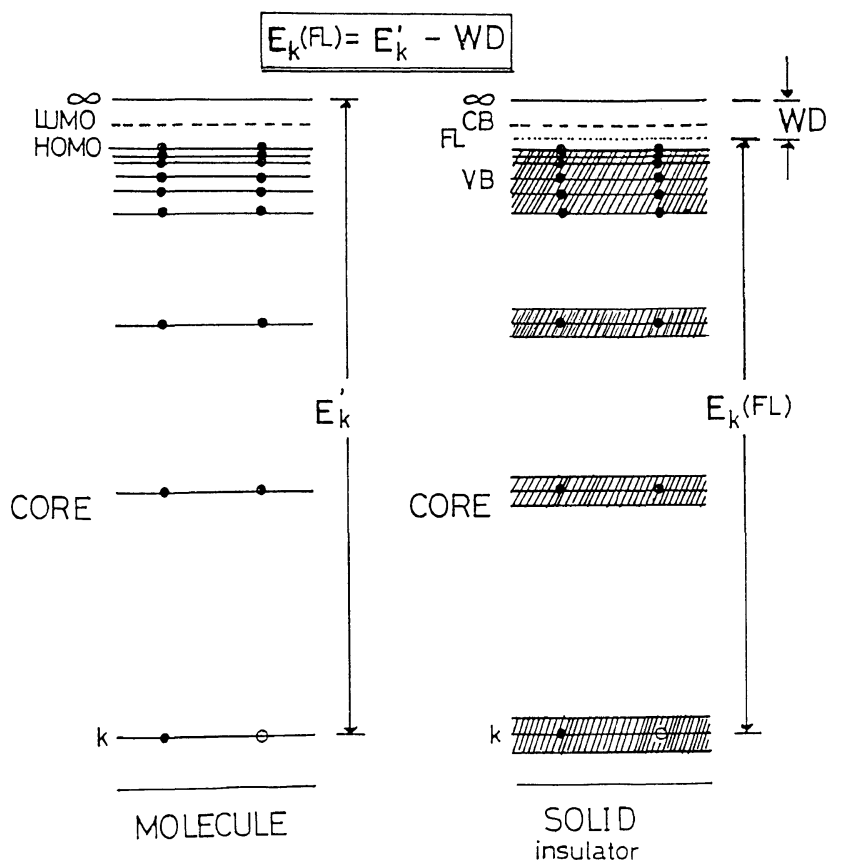

Figure 4. Comparative diagram of energy levels between calculated or observed CEBEs for single model molecule and observed CEBEs on a solid polymer. The relation $E_{\mathbf{k}}\left(E_{\mathrm{F}}\right)=E_{\mathbf{k}}^{\prime}-W D$, where $E_{\mathbf{k}}^{\prime}$ and $E_{\mathrm{k}}\left(E_{\mathrm{F}}\right)$ are each computed or observed CEBE of the molecule and observed CEBE of solid polymer relative to the Fermi level. $W D$ denotes the sum of the work function of the sample polymer and other energy effects.

\section{CEBEs and WD of Six Polymers}

In previous papers, ${ }^{17-21}$ we stated that the MO eigenvalues can give the CEBEs or vertical ionization potentials directly in the MO theory which used the
Table II. Cls binding energies and $W D$ s of $\mathrm{N}-, \mathrm{O}-$, and $\mathrm{X}$-containing polymers by deMon density-functional program using the model molecules ${ }^{\mathrm{a}}$ (in eV)

\begin{tabular}{|c|c|c|c|}
\hline Polymer & Observed $^{\mathbf{b}}$ & $\begin{array}{l}\text { Model } \\
\text { molecule }\end{array}$ & $\begin{array}{l}\text { uGTS scaled } \\
\text { pVTZ } \\
\left(W D^{\mathrm{c}}\right)\end{array}$ \\
\hline $\begin{array}{l}\left(\mathrm{CH}_{2}-\mathrm{CH}_{2}-\mathrm{NH}\right)_{n} \\
\quad \mathrm{CEBE}(\mathrm{Cls})\left[\mathrm{CH}_{2-}\right]\end{array}$ & 285.6 & $2 \mathrm{mer}$ & $291.58(6.0)$ \\
\hline $\begin{array}{l}\left(\mathrm{CH}_{2}-\mathrm{CH}(\mathrm{CN})\right)_{n} \\
\quad \mathrm{CEBE}(\mathrm{Cls})[-\mathrm{CH}]\end{array}$ & 286.4 & 1 mer-m & $292.79(6.4)$ \\
\hline $\begin{array}{l}\left(\mathrm{CH}_{2}-\mathrm{CHF}\right)_{n} \\
\quad \mathrm{CEBE}(\mathrm{Cls})[\underline{\mathrm{CHF}}]\end{array}$ & 287.9 & $2 \mathrm{mer}$ & $293.15(5.3)$ \\
\hline $\begin{array}{l}\left(\mathrm{CH}_{2}-\mathrm{CF}_{2}\right)_{n} \\
\quad \mathrm{CEBE}(\mathrm{C} 1 \mathrm{~s})\left[\mathrm{CF}_{2-}\right]\end{array}$ & 290.9 & $2 \mathrm{mer}$ & $296.08(5.2)$ \\
\hline $\begin{array}{l}\left(\mathrm{CH}_{2}-\mathrm{CHCl}\right)_{n} \\
\quad \mathrm{CEBE}(\mathrm{Cls})[\underline{\mathrm{CHCl}}]\end{array}$ & 287.0 & 2 mer & $292.77(5.8)$ \\
\hline $\begin{array}{l}\left(\mathrm{CH}_{2}-\mathrm{CCl}_{2}\right)_{n} \\
\quad \mathrm{CEBE}(\mathrm{Cls})\left[\mathrm{CCl}_{2}\right]\end{array}$ & 288.6 & $2 \mathrm{mer}$ & $293.99(5.4)$ \\
\hline
\end{tabular}

${ }^{a}$ We omitted the contribution of both edge segments of the main chain. ${ }^{b}$ Values were referred to G. Beamson and D. Briggs, "High Resolution XPS of Organic Polymers. The Scienta ESCA 3000 Database." Wiley, Chichester, 1992. " Values denote the differences between the calculated CEBEs using uGTS model and the observed ones.

Slater's idea of the transition-state. Then, for the comparison between calculations for single molecules of the monomer or dimer models and experiments on a solid polymer, we can shift each computed CEBEs, $E_{\mathbf{k}}^{\prime}$ by a quantity $W D$ as $E_{\mathrm{k}}\left(E_{\mathrm{F}}\right)=E_{\mathrm{k}}^{\prime}-W D$, to convert to CEBE $E_{\mathrm{k}}\left(E_{\mathrm{F}}\right)$ relative to the Fermi level (Figure 4). In 
the figure, we can assume that the HOMO and LUMO in the molecule correspond to the highest level of the valence band and the lowest level of the conduction band in a solid polymer. The calculated CEBEs (Table II) of model molecules for six polymers (poly(ethyleneimine) (PEI), poly(acrylonitrile) (PAN), poly(vinylidene fluoride) (PVF), poly(vinylidene difluoride) (PVDF), (PVC), and poly(vinylidene difluoride) (PVDC)) using uGTS model are much closer to observed values, in comparison with those values predicted by Koopmans' theorem, as shown in Table I. For the CEBEs with scaled-pVTZ basis set including the relativistic corrections, we obtained values of $W D$ for the polymers as $5.2-6.4 \mathrm{eV}$ from the difference between the calculated CEBEs of the model molecules and experimental CEBEs of the polymers. The values seem to reflect the reliable $W D$ of polymers.

For $W D$ of PVC polymer, the work function was already given as 4.85 or $5.13 \mathrm{eV}$ by electrical measurement, ${ }^{22,23}$ while the polarization energy of other energy effects for $W D$ was obtained as $1.5 \mathrm{eV}$ from UPS analysis. ${ }^{24}$ Thus we can evaluate the values of $W D$ as 6.3 or $6.6 \mathrm{eV}$. The values may reflect the $W D(5.8 \mathrm{eV})$ of $\mathrm{PVC}$ in Table II.

\section{CONCLUSION}

C1s X-ray photoelectron spectra of N-, O-, F-, and Cl-containing polymers were simulated from Koopmans' theorem by $a b$ initio MO calculations of HONDO7 program using the model molecules. The theoretical spectra showed fairly good accordance with the experimental spectra, although we used the energy shifted value and the linewidth of a Gaussian lineshape function for each MO value as $21.0 \mathrm{eV}$ and $1.3 \mathrm{eV}$, respectively.

The core-electron binding energies (CEBEs) of $\mathrm{C} 1 \mathrm{~s}$ for model molecules of polymers $\left[\left(\mathrm{CH}_{2}-\mathrm{CH}_{2}-\mathrm{NH}\right)_{n},\left(\mathrm{CH}_{2}-\right.\right.$ $\left.\mathrm{CHR})_{n}(\mathrm{R}=\mathrm{CN}, \mathrm{F}, \mathrm{Cl}),\left(\mathrm{CH}_{2}-\mathrm{CX}_{2}\right)_{n}(\mathrm{X}=\mathrm{F}, \mathrm{Cl})\right]$ were calculated by deMon density functional theory program with scaled polarized valence triple-zeta (scaled-pVTZ) basis set. The reliable values of WD (sum of work funktion and other energy effects) of the polymers were obtained as $5.2-6.4 \mathrm{eV}$ from the difference between the calculated CEBEs of the model molecules and the experimental CEBEs of the polymers.

Acknowledgment. We are grateful to Professor D. P. Chong of University of British Columbia for their valuable suggestion for the $a b$ initio DFT calculations using deMon program. We thank Dr. D. R. Salahub of University of Montreal for an early version of the deMon density functional program.

\section{REFERENCES}

1. K. Endo, C. Inoue, N. Kobayashi, T. Higashioji, and H. Nakatsuji, Bull. Chem. Soc., Jpn., 66, 3241 (1993).

2. K. Endo, C. Inoue, N. Kobayashi, and M. Aida, J. Phys. Chem. Solids, 55, 471 (1994).

3. C. Inoue, Y. Kaneda, M. Aida, and K. Endo, Polym. J., 27, 300 (1995).

4. K. Endo, S. Maeda, and M. Aida, Polym. J., 29, 171 (1997).

5. M. S. Dupuis, J. D. Watts, H. G. Villar, and G. J. B. Hurst, HONDO, version 7; Scientific and Engineering Computations Dept. 48B IBM Corp.; New York, 12401; 1978.

6. A. St-Amant and D. R. Salahub, Chem. Phys. Lett., 169, 387 (1990); A. St-Amant, Ph. D. Thesis, University of Montreal, (1991).

7. S. Huzinaga, J. Andzelm, M. Klobukoski, E. Radzio-Andzelm, Y. Sakai, and H. Takewaki, Gaussian Basis Sets for Molecular Calculations. Elsevier, Amsterdam, 1984.

8. T. H. Dunning Jr. and P. J. Hay, in "Methods of Electronic Structure Theory," H. F. Schaefer, III, Ed., Plenum, New York N.Y., 1977.

9. M. J. S. Dewar and E. G. Zoebisch, Theochem., 180, 1 (1988); M. J. S. Dewar, E. G. Zoebisch, E. F. Healy, and J. J. P. Stewart, J. Am. Chem. Soc., 107, 3902 (1985).

10. A. R. Williams, R. A. deGroot, and C. B. Sommers, J. Chem. Phys., 63, 628 (1975).

11. J. C. Slater, Advan. Quantum Chem., 6, 1 (1972).

12. J. F. Janak, Phys. Rev. A, 18, 7165 (1978).

13. A. D. Becke, Phys. Rev. A, 38, 3098 (1988).

14. J. P. Perdew, Phys. Rev. B, 33, 8822 (1986).

15. D. P. Chong, J. Chem. Phys., 103, 1842 (1995).

16. G. Beamson and D. Briggs, "High Resolution XPS of Organic Polymers. The Scienta ESCA 3000 Database.” Wiley, Chichester, 1992

17. K. Endo, Y. Kaneda, M. Aida, and D. P. Chong, J. Phys. Chem. Solids, 56, 1131 (1995).

18. M. Aida, Y. Kaneda, N. Kobayashi, K. Endo, and D. P. Chong, Bull. Chem. Soc. Jpn., 67, 2972 (1994).

19. K. Endo, C. Inoue, Y. Kaneda, M. Aida, N. Kobayashi, and D. P. Chong, Bull. Chem. Soc. Jpn., 68, 528 (1995).

20. K. Endo, Y. Kaneda, H. Okada, D. P. Chong, and P. Duffy, J. Phys. Chem., 100, 19455 (1996).

21. K. Endo, M. Aida, H. Okada, D. P. Chong, and P. Duffy, to be published.

22. C. F. Gallo and W. L. Lama, IEEE Trans. Ind. Applic., IA-12, 7 (1976).

23. K. Mittal, J. Vac. Sci. Technol., 13, 19 (1976).

24. C. S. Xian, K. Seki, H. Inokuchi, S. Hashimoto, N. Ueno, and K. Sugita, Bull. Chem. Soc. Jpn., 58, 890 (1985). 